October 5, 2007

The Honorable Edward M. Kennedy

Chairman

Committee on Health, Education, Labor, and Pensions

United States Senate

Dear Mr. Chairman:

Subject: School Mental Health: Role of the Substance Abuse and Mental Health Services Administration and Factors Affecting Service Provision

The U.S. Surgeon General reported in 1999 that about one in five children in the United States suffers from a mental health problem that could impair their ability to function at school or in the community. Yet many children receive no mental health services. While many of the existing mental health services for children are provided in schools, the extent and manner of school mental health service delivery vary across the country and within school districts. ${ }^{1}$

Federally led initiatives have identified schools as a potentially promising location for beginning to address the mental health needs of children. Both the report of the Surgeon General's Conference on Children's Mental Health and the 2003 report of the President's New Freedom Commission on Mental Health-Achieving the Promise: Transforming Mental Health Care in America-identified school mental health services as a means of improving children's mental and emotional well-being. ${ }^{2}$

At the federal level, the Department of Health and Human Services' (HHS) Substance Abuse and Mental Health Services Administration (SAMHSA) has a stated mission of building resilience and facilitating recovery for people-including children at risk for mental health problems. Although SAMHSA is the federal government's lead agency for mental health services, other federal agencies and departments, such as HHS's Centers for Disease Control and Prevention (CDC) and the Department of Education (Education), engage in, or

\footnotetext{
${ }^{1}$ For the purposes of this report, we use the term "school mental health services" to refer to both school-based services, i.e., services provided in the school, and school-linked services, i.e., services provided by a community provider through a link with the school. Throughout this report, the term school is used to refer to elementary and secondary education, i.e., kindergarten through 12th grade.

${ }^{2}$ U.S. Public Health Service, Report of the Surgeon General's Conference on Children's Mental Health: A National Action Agenda, Department of Health and Human Services (Washington, D.C.: Sept. 18-19, 2000) and New Freedom Commission on Mental Health, Achieving the Promise: Transforming Mental Health Care in America: Final Report, Department of Health and Human Services (Rockville, Md.: July 22, 2003).
} 
coordinate ${ }^{3}$ activities related to school mental health services in various ways. SAMHSA works to achieve its mission chiefly by providing grants and technical assistance. ${ }^{4}$ For example, the agency uses grant funds and technical assistance to support the expansion of mental health service capacity and the use of evidence-based practices in mental health services. Typically, efforts that have been validated by some form of documented scientific data are referred to as evidence-based.

You asked us to provide information on school mental health services and the role of SAMHSA in this area. In this report, we describe (1) SAMHSA's coordination with other federal departments and agencies to support mental health services in schools, (2) the efforts SAMHSA has made to identify and support evidence-based school mental health services and best practices for service delivery, and (3) factors that affect the provision of mental health services in schools.

To address these objectives, we reviewed materials related to SAMHSA's efforts to coordinate activities related to school mental health services with other federal departments and agencies. We also reviewed materials related to SAMHSA's efforts to identify and support the use of evidence-based interventions. These materials included program descriptions and grant announcements related to federal programs that support school mental health services, as well as agendas and summary documents from interagency meetings related to children's mental health. We conducted interviews with SAMHSA staff, as well as staff from other HHS agencies who interact with SAMHSA or conduct activities related to school mental health services. In addition, we interviewed staff from Education's Office of Safe and Drug-Free Schools and the Department of Justice's (DOJ) Office of Justice Programs, which participate in activities related to mental health services and violence prevention programs in schools. We also interviewed experts in the field of mental health services and representatives of mental health provider groups and school administration associations. Information on mental health services provided to students who qualify for special education services through the Individuals with Disabilities Education Act (IDEA) was outside the scope of our work. ${ }^{5}$

To provide information on factors that affect the provision of school mental health services, we conducted interviews with representatives from seven selected sites-schools and school districts—and reviewed documents, including their program descriptions, training materials,

\footnotetext{
${ }^{3}$ Coordination can be broadly defined as any joint activity by two or more organizations that is intended to produce more public value than could be produced when organizations act alone. For the purposes of this report, we use the term "coordination" to include activities variously described as "cooperation," "collaboration," "integration," and "networking." See GAO, Results-Oriented Government: Practices That Can Help Enhance and Sustain Collaboration among Federal Agencies, GAO-06-15 (Washington, D.C.: October 2005).
}

${ }^{4}$ In this report, we use the term grants to include both grants and cooperative agreements, except where otherwise indicated. The distinction between a grant and a cooperative agreement is the degree of federal involvement. A cooperative agreement is used when substantial involvement is expected between an agency and the funding recipient, whereas a grant is used when substantial involvement is not expected between an agency and the funding recipient. In addition, for the purposes of this report, we use the term technical assistance to refer to support provided to organizations receiving federal funding to help them with the implementation of their program, such as assistance with strategic planning or program evaluation.

${ }^{5}$ IDEA provides funding to support free, appropriate public educational services to children with disabilities, including disabilities related to mental health. 20 U.S.C. $§ 1400$ et seq. 
and evaluation reports. We conducted interviews on site at five locations, two in Connecticut and three in Ohio; and by telephone with two locations, one in Florida and one in North Carolina.

To select our seven sites we

- Interviewed officials from federal agencies and associations, as well as experts in the area of school mental health, to identify states, localities, school districts, and specific schools considered to be active in the area of school mental health services.

- Selected a sample of 7 sites from approximately 53 identified locations based on the following criteria: The sites selected were to include a mix of urban and rural settings, settings with school-based health centers, and at least 1 site currently receiving funds through the federal Safe Schools/Healthy Students (SS/HS) and Grants for the Integration of Schools and Mental Health Systems Programs.

Because we used a nongeneralizable sample to select our sites, the information provided cannot be used to make inferences about other programs. In addition, the information provided by program officials does not reflect all efforts under way in their locations related to school mental health services. (For additional information on our methodology, see encl. I. For more information on sites in our review, see encl. II.)

We conducted our work from March 2007 through September 2007 in accordance with generally accepted government auditing standards.

\section{Results in Brief}

SAMHSA coordinates formally and informally with other federal departments and agencies on school mental health services. The agency currently maintains two formal coordination efforts for school mental health services. It coordinates with (1) Education and DOJ for the SS/HS initiative, a key federal effort to directly support mental health services in schools; and (2) several federal departments and agencies serving children, including Education and DOJ, for the Federal/National Partnership, an effort designed to promote coordination related to children's mental health and substance use prevention. In addition to formal coordination efforts, SAMHSA officials maintain multiple informal or episodic coordination efforts with other federal departments and agencies, such as Education, CDC, and the Health Resources and Services Administration (HRSA), on a variety of activities related to school mental health services; these are based largely on personal relationships among agency staff.

SAMHSA both identifies and supports the use of evidence-based school mental health interventions. To identify evidence-based interventions, SAMHSA uses the National Registry of Evidence-based Programs and Practices (NREPP). This searchable registry assists interested parties, including school and school district staff members, in identifying interventions to provide mental health services for children in schools. As of August 2007, slightly more than one-fourth of the interventions listed on NREPP were related to school mental health, including interventions designed to address aggressive behavior, depression, or school violence. SAMHSA also supports the use of evidence-based school mental health interventions through grant programs, including the SS/HS program. SS/HS requires grantees to use evidence-based interventions and provides technical assistance for the implementation of these interventions. SAMHSA also awards grants to support the use of evidence-based interventions through other programs not specifically designed for the school setting. 
Officials from the seven sites in our review identified coordination and close working relationships, support from "program champions"-advocates for the program-and school leadership, and sustainable funding and staffing as factors that can affect the provision of school mental health services. Because mental health professionals focus on students' emotional health and education professionals focus on academic achievement, coordination between these differing missions can enhance the provision of school mental health services. School officials from sites in our review recognized that addressing students' mental health needs can improve their academic achievement. Site officials told us that, in addition to being aware of a school's academic mission, mental health providers need to be cognizant of students' academic schedules and responsibilities. For example, sites avoided providing services during testing periods. Coordination between sites and external stakeholders, such as community mental health or social service agencies, can also enhance the provision of school mental health services by allowing schools to build relationships with other agencies that influence the lives of students. Sites also emphasized the importance of working closely with existing school health and mental health staff. By doing this, sites can avoid overlap in services provided to students. Site officials stressed that one or more program champions and support from school leaders can play a role in implementing school mental health services; conversely, the loss of either of these can threaten program continuity. Finally, site officials noted that difficulties securing and sustaining both funding and mental health service provider staff have affected the ability to implement school mental health services.

In commenting on a draft of this report, HHS agreed with our characterization of SAMHSA's efforts related to school mental health services and stressed the importance of schools as a venue for the delivery of mental health prevention and treatment programs, services, and supports. Education told us it had no comments on the draft.

\section{Background}

Multiple federal agencies are involved to varying degrees in school mental health services at the elementary and secondary level, including through grants and technical assistance. While school mental health services vary from location to location, most schools have some efforts in place to address students' mental health needs, which can be provided by a variety of mental health professionals.

\section{Federal Role in Education and Mental Health Services for Children}

Elementary and secondary education is primarily a responsibility of states and localities. During the 2003-2004 school year, Education reported that the state and local share of total revenues related to elementary and secondary education equaled 91 percent-just over $\$ 420$ billion. While state and local agencies take the lead in elementary and secondary education, a variety of federal departments and agencies are involved in supporting or promoting mental health in schools.

SAMHSA has primary federal responsibility for issues related to children's mental health services. ${ }^{6}$ SAMHSA's Center for Mental Health Services supports mental health services that are evidence-based, provided in community settings, and designed to promote recovery for people with, or at risk for, mental health disorders. The center provides this support through

${ }^{6}$ SAMHSA's total fiscal year 2007 budget was about $\$ 3.2$ billion. 
grants and technical assistance, and acts as SAMHSA's lead in the SS/HS program, an effort that directly supports mental health services in schools. Since its creation in 1999, the SS/HS grant program, a joint effort of SAMHSA, Education, and DOJ, has awarded more than $\$ 1$ billion to support school mental health services and related activities. The program is designed to promote safe, drug-free schools and healthy childhood development and includes efforts to promote positive student behavior and early identification and treatment of mental health problems. (See encl. III for more information on the SS/HS program.) SAMHSA funds other programs related to children's mental health that, while not focused on schools, relate to school programs or efforts in the area of school mental health.

In addition to SAMHSA, other agencies within HHS have roles related to school mental health services. For example,

- HRSA funds the Mental Health in Schools Program to support two centers related to school mental health. ${ }^{7}$ These centers currently focus on analysis of school mental health policies and programs and have also provided training and technical assistance. Fiscal year 2007 funding for this program was $\$ 900,000$. HRSA's Health Center Program, funded at approximately $\$ 1.78$ million in fiscal year 2006 , supports community health centers, including centers designed to provide services to specific populations such as migrant workers, residents of public housing, and at-risk school students. Services to students can be provided through school-based health centers, which may provide mental health services such as case management or therapy.

- CDC has developed the Coordinated School Health Program model, made up of eight interrelated components addressing student health, one of which is counseling and psychological services. CDC also has a cooperative agreement with the National Assembly on School-Based Health Care, an organization whose mission is to support school-based health centers, for a 5-year "School Mental Health Capacity Building Partnership" initiative. This initiative, which according to CDC officials is funded at $\$ 175,000$ per year, is designed to strengthen efforts to improve school mental health services and synthesize information on state and local efforts in this area. CDC surveys, including student surveys and surveys of school and school district staff, also collect information directly or indirectly related to school mental health services.

- The National Institutes of Health's National Institute of Mental Health (NIMH) funds research on school mental health services and service delivery models.

- The Centers for Medicare and Medicaid Services' Medicaid program, a joint federal-state program to finance health care coverage for certain categories of low-income individuals, can in some cases be used to pay for specific school mental health services. For example, in some states, Medicaid may pay for diagnosis of mental health issues or therapy provided in a school setting for students enrolled in Medicaid.

\footnotetext{
${ }^{7}$ These centers are the Center for Mental Health in Schools at the University of California, Los Angeles and the Center for School Mental Health Analysis and Action at the University of Maryland, Baltimore.
} 
Other federal departments also support programs related to school mental health services. For example,

- Education's Office of Safe and Drug-Free Schools participates in the SS/HS program. In addition, it funds both the Grants for the Integration of Schools and Mental Health Systems program, a grant program designed to help school systems develop connections with local mental health systems, and the Elementary and Secondary School Counseling program, which provides funding to school systems to establish or expand elementary and secondary school counseling programs. ${ }^{8}$ Grants for these two programs totaled just under $\$ 40$ million in fiscal year 2007. Education also supports Project School Emergency Response to Violence (Project SERV), a grant program that funds short-term and longterm education-related services, including mental health assessments, referrals, and counseling services, to school systems in which the learning environment has been affected by a violent or traumatic event. In fiscal year 2007, Project SERV was funded at $\$ 3$ million. ${ }^{9}$

- DOJ also participates in the SS/HS program. In addition, the Office of Justice Programs has funded efforts to develop resources related to youth violence and truancy prevention, which may involve mental health programs in school settings. Through the Antiterrorism and Emergency Assistance Program for Terrorism and Mass Violence, the Office for Victims of Crime (OVC) provides funds to states and localities, including schools, to address issues, including mental health needs, stemming from intentional acts of criminal mass violence. For example, OVC officials reported that the program provided funds following the September 2006 shooting at Platte Canyon High School in Bailey, Colorado.

\section{Delivery of School Mental Health Services to Children}

Because decisions related to schools are typically made at the local level, school mental health service delivery varies from district to district, and can vary from school to school within the same district. A variety of services can be provided, including prevention activities, assessment, crisis intervention, case management, and counseling. Efforts can focus on a wide range of problems, including specific mental health diagnoses, bullying, violence, and discipline issues.

Studies indicate that most of the approximately 90,000 public schools nationwide have various efforts in place to address the mental health needs of their students. ${ }^{10}$ While the mechanisms for delivering school mental health services vary greatly from location to location, several general delivery mechanisms have been identified: ${ }^{11}$

- School student support services: Services provided by school-employed staff such as counselors or psychologists.

${ }^{8}$ Funding can be awarded to secondary schools only if grant funds exceed $\$ 40$ million.

${ }^{9}$ Funds appropriated for Project SERV remain available for awards in subsequent years if not used.

${ }^{10}$ S. Foster et al., School Mental Health Services in the United States, 2002-2003 (Rockville, Md.: Center for Mental Health Services, SAMHSA, 2005).

${ }^{11}$ These mechanisms are not mutually exclusive. For more information, see Center for Mental Health in Schools, The Current Status of Mental Health in Schools: A Policy and Practice Analysis (Los Angeles, Calif.: 2006). 
- School-district mental health units: Services provided to students through a districtoperated mental health unit or clinic.

- Agreements for services with community providers: Services provided through an agreement between the schools and a community provider, such as a school-based health center run by an entity other than the school or school district.

- Classroom-based curricula: Services provided through curricula in classrooms or as special programs, such as activities to promote healthy emotional behavior and prevent behavioral problems.

- Comprehensive, multifaceted, and integrated approaches: Services provided through comprehensive systems that bring together resources from both schools and communities in an integrated fashion to promote student mental health.

According to a 2005 SAMHSA report, during the 2002-2003 school year about one-third of school districts surveyed provided mental health services using only school or school district employees. ${ }^{12}$ More than half of the schools surveyed reported that they contracted with one or more community organizations or individual providers for mental health services. Almost 30 percent of these schools reported that they contracted with their local mental health agency, while others reported contracting with a variety of public and private providers. Six percent and 4 percent of schools, respectively, reported contracting with hospitals or faithbased organizations.

Regardless of the mechanism used, services generally fall into three categories-universal, selective, or indicated: ${ }^{13}$

- Universal: Services intended for all children, including services related to creating a positive school environment or improving students' social skills. These services may focus on decreasing risk factors for future mental health problems and increasing resilience by promoting positive school environments and ensuring that students have access to appropriate supports to allow healthy emotional development.

- Selective: Services targeting a smaller subset of the population, usually those children identified as at-risk for developing mental health problems or with identified mental health needs. Services at this level may include targeted violence-, suicide-, or dropoutprevention programs or group therapy.

- Indicated: Services targeting children with the greatest need for support, which could include intensive services such as one-on-one therapy.

\footnotetext{
${ }^{12}$ S. Foster et al.

${ }^{13}$ Other models for these categories exist. For more information on various models, see K. Kutash, A.J. Duchnowski, and N. Lynn, School-Based Mental Health: An Empirical Guide for Decision-Makers (Tampa, Fla.: University of South Florida, 2006).
} 


\section{$\underline{\text { Staffing of Mental Health Service Provision in Schools }}$}

Providers of various types - school counselors, psychologists, social workers, nurses, marriage and family therapists, and others-can address students' mental health needs in schools. The roles of these professionals overlap to some extent, but each has particular areas of expertise. (See table 1.)

Table 1: Selected Professions That May Provide School Mental Health Services

\begin{tabular}{|c|c|c|c|}
\hline Provider type & Provider description & $\begin{array}{l}\text { Provider association's } \\
\text { recommended provider- } \\
\text { to-student ratio }^{\mathrm{a}}\end{array}$ & $\begin{array}{l}\text { Provider association's } \\
\text { recommended training } \\
\text { level }^{\mathrm{a}}\end{array}$ \\
\hline $\begin{array}{l}\text { School } \\
\text { counselors }\end{array}$ & $\begin{array}{l}\text { Provide services designed to } \\
\text { address students' academic, } \\
\text { career, and personal/social } \\
\text { development. These services can } \\
\text { include individual or group } \\
\text { counseling, consultation with } \\
\text { parents and teachers, and referrals } \\
\text { to other school or community } \\
\text { resources. }\end{array}$ & $\begin{array}{l}1 \text { school counselor to } \\
\text { every } 250 \text { students }\end{array}$ & Master's level \\
\hline $\begin{array}{l}\text { School } \\
\text { psychologists }\end{array}$ & $\begin{array}{l}\text { Assess students' psychological } \\
\text { functioning and needs, and provide } \\
\text { consultation to parents and school } \\
\text { staff on students' behavioral, social, } \\
\text { emotional, and instructional needs. } \\
\text { May provide some prevention and } \\
\text { direct intervention services. May } \\
\text { focus on assessment of the special } \\
\text { education population. }\end{array}$ & $\begin{array}{l}1 \text { school psychologist to } \\
\text { every } 1,000 \text { students }\end{array}$ & $\begin{array}{l}\text { Post-master's specialist- } \\
\text { level degree program }\end{array}$ \\
\hline $\begin{array}{l}\text { School social } \\
\text { workers }\end{array}$ & $\begin{array}{l}\text { Provide services designed to create } \\
\text { linkages among the school, family, } \\
\text { and community, including case } \\
\text { management, support groups, } \\
\text { crisis intervention, and home visits. }\end{array}$ & $\begin{array}{l}1 \text { school social worker to } \\
\text { every } 400 \text { students }\end{array}$ & Master's level \\
\hline School nurses & $\begin{array}{l}\text { Implement school health services, } \\
\text { including mental health, for all } \\
\text { students. Can provide services } \\
\text { including chronic care, general } \\
\text { health education and promotion } \\
\text { activities, and teacher education. } \\
\text { May also act as a contact within } \\
\text { the school for a family. }\end{array}$ & $\begin{array}{l}1 \text { school nurse to every } \\
750 \text { students }\end{array}$ & $\begin{array}{l}\text { Licensure as a registered } \\
\text { nurse and a baccalaureate } \\
\text { degree }\end{array}$ \\
\hline $\begin{array}{l}\text { Marriage and } \\
\text { family therapists }\end{array}$ & $\begin{array}{l}\text { Diagnose and treat mental and } \\
\text { emotional disorders within the } \\
\text { context of marriage, couples, and } \\
\text { family systems. While not exclusive } \\
\text { to schools, some work in school } \\
\text { settings. }\end{array}$ & No recommended ratio & Master's level \\
\hline
\end{tabular}

Source: GAO analysis of information from HRSA and provider associations.

${ }^{a}$ Recommended by the relevant provider association: American School Counselor Association, National Association of School Psychologists, School Social Work Association of America, National Association of School Nurses, and the American Association for Marriage and Family Therapy.

SAMHSA's 2005 report identified school counselors as the most common type of school mental health provider, followed by school psychologists and school social workers. The study also found that school nurses, with broad responsibility for student health needs, spend one-third of their time providing mental health services. In addition to the credentials 
recommended by provider associations, a 2000 study found that most states and school districts have developed minimum education and certification requirements for school staff who provide mental health services. ${ }^{14}$ Of states with minimum educational requirements, most required a master's degree for counselors and psychologists, while fewer than half required a master's degree for social workers. ${ }^{15}$

\section{SAMHSA Coordinates Formally and Informally at the Federal Level on School Mental Health Services}

SAMHSA coordinates with other federal departments and agencies on school mental health services. SAMHSA currently maintains two formal coordination efforts for school mental health services - it coordinates with (1) Education and DOJ for the SS/HS initiative and (2) several federal departments and agencies serving children for the Federal/National Partnership, an effort designed to promote collaboration related to children's mental health and substance use prevention. In addition to formal coordination efforts, SAMHSA officials maintain multiple informal or episodic coordination efforts at the federal level related to school mental health services.

$\underline{\text { SAMHSA Formally Coordinates with Federal Departments and Agencies on an Ongoing Basis }}$

SAMHSA, Education, and DOJ have coordinated on SS/HS by contributing financial, technical, and administrative support through a collaborative agreement. ${ }^{16}$ SAMHSA's funds are used for mental health promotion, prevention, early identification, and treatment services and supports for students and their families. These activities can include early identification and assessment in the school setting, and early childhood development programs, such as nurse home visits for young children who demonstrate behavior problems. The funds contributed by Education and DOJ have been used for alcohol, drug, and violence prevention and early intervention programs, as well as efforts to address student behavioral, social, and emotional supports. ${ }^{17}$

\footnotetext{
${ }^{14}$ N.D. Brener, J. Martindale, and M.D. Weist, "Mental Health and Social Services: Results from the School Health Policies and Programs Study 2000," Journal of School Health (2001): 305-312. The 2000 School Health Policies and Programs Study provides the most recent data available and is based on data from the 50 states plus the District of Columbia and a nationally representative sample of school districts. CDC officials anticipate that new data from the study will be available in fall 2007.

${ }^{15}$ The study does not collect information regarding marriage and family therapists or other provider types.

${ }^{16}$ While the collaborative agreement that guides the SS/HS program has not changed, DOJ has not contributed funds since fiscal year 2003 and does not currently have staff assigned to the SS/HS program. However, the agency still participates in making programmatic decisions, including grant decisions, under the collaborative agreement.

${ }^{17}$ Although Education's SS/HS funds can be used for prevention and early intervention programs, Education cannot use these funds for medical services (including mental health treatment) or drug treatment or rehabilitation, except for pupil services or referral to treatment for students who are victims of, or witnesses to, crime or who illegally use drugs. 20 U.S.C. $§ 7164$.
} 
SAMHSA and DOJ have made funds available to Education, which also contributes funds. Education acts as fiscal agent of the program and issues grant awards. In addition, the agencies have coordinated peer reviews of SS/HS grant applications, ${ }^{18}$ while Education collects and maintains final grantee progress and financial reports. SAMHSA also has a cooperative agreement with a national organization to provide technical assistance to SS/HS grantees. According to SAMHSA officials, the agency coordination effort for SS/HS is organized into two teams, which meet to discuss issues related to the program: (1) an interagency policy team made up of high-level representatives from each agency, and (2) a supervisory team consisting of agency staff who discuss day-to-day management issues, including staff assignments and scheduling. In addition, program officers from SAMHSA and Education-nine in total-monitor and manage from 11 to 18 grants each and meet monthly to discuss issues related to the program. Experts in school mental health services told us that the SS/HS is a good example of effective coordination at the federal level.

SAMHSA's coordination with Education and DOJ for the SS/HS program includes key practices that we have identified as helping to enhance and sustain coordination among federal agencies. ${ }^{19}$ To define and articulate a common program outcome, the agencies overcame the differences in agency missions by identifying a common mission-to create safe school environments and healthy students. This effort to identify a common mission was designed to create a seamless program for grantees at the local level. To establish mutually reinforcing or joint strategies for the program, agency leadership at the three agencies vested decision-making authority in officials such as division directors and branch chiefs, who assigned their staff to the SS/HS effort. The agencies established compatible policies, procedures, and other means to operate across agency boundaries and agreed on each agency's roles and responsibilities. For example, because each agency had different program monitoring policies, officials created a program monitoring system that was consistent across all three agencies. ${ }^{20}$ To develop mechanisms to monitor, evaluate, and report on results, the agencies built an evaluation component into the SS/HS program at the federal and local levels-grantees are required to conduct local evaluations, and the federal agencies are conducting a national evaluation for SS/HS. ${ }^{21}$

\footnotetext{
${ }^{18}$ Grant applications are screened by federal SS/HS staff and then forwarded to a contractor for peer review. The peer review panel is organized by the contractor and is made up of three independent reviewers, with a federal program officer acting as a discussion facilitator. The list of applications ranked by reviewers' scores is provided to SAMHSA, Education, and DOJ for review prior to final grant awards. In fiscal year 2007, 27 new grants were awarded.

${ }^{19}$ These key practices are (1) defining and articulating a common outcome; (2) establishing mutually reinforcing or joint strategies; (3) identifying and addressing needs by leveraging resources; (4) agreeing on roles and responsibilities; (5) establishing compatible policies, procedures, and other means to operate across agency boundaries; (6) developing mechanisms to monitor, evaluate, and report on results; (7) reinforcing agency accountability for collaborative efforts through agency plans and reports; and (8) reinforcing individual accountability for collaborative efforts through performance management systems. See GAO-06-15.

${ }^{20} \mathrm{An}$ official from DOJ noted that when creating this system, all the agencies agreed that if they could not reach consensus, they would use Education's policy or procedure, because of Education's role as fiscal agent for the grant. However, SAMHSA officials noted this has not been necessary as the agencies have been able to reach consensus.
}

${ }^{21}$ SAMHSA and NIMH also co-sponsor a program announcement for SS/HS grantee sites to participate in research opportunities unrelated to the national and local evaluations. 
SAMHSA's other formal coordination effort is the Federal/National Partnership, formed in 2004 with SAMHSA designated as the lead agency. ${ }^{22}$ The purpose of this partnership is to promote collaboration among federal agencies to transform children's mental health and substance abuse delivery systems nationally. The partnership includes representatives from key federal agencies that serve children, national organizations, and family and youth organizations. ${ }^{23}$ During its first meeting in November 2004, the partnership established three workgroups focused on children's mental health issues, one of which is the Integration of Mental Health and Education Workgroup, which is focused on school mental health services. ${ }^{24}$ The purpose of this workgroup is to develop a coordinated federal process to support integration of school mental health services.

SAMHSA convened a meeting in August 2006 to begin planning the Integration of Mental Health and Education Workgroup. At the August 2006 meeting, a variety of organizations that provide technical assistance related to children's mental health were brought together and a core group of participants identified. As of July 2007, some tasks identified at the August 2006 meeting had been completed. For example, SAMHSA has compiled a list of programs by topic area, which can be found on the agency's Web site. Program topics include school mental health, suicide prevention, youth violence prevention, and other programs related to mental health and substance abuse issues for children and families. SAMHSA also organized events for National Children's Mental Health Awareness Day in May 2007, which focused on school mental health services. Other tasks are in progress. For example, a logic model-a model that describes how an initiative should work and anticipated outcomes-for the integration of education and mental health in schools is being developed. SAMHSA officials expect to convene the first workgroup meeting in fall 2007 and plan to include participation by education professionals and other federal agencies. The agency also plans to invite participation from representatives of community-based organizations and school-employed providers.

SAMHSA Officials Coordinate with Federal Departments and Agencies on an Informal or Episodic Basis

SAMHSA officials maintain informal or episodic coordination efforts on issues related to school mental health services with Education and other HHS agencies such as HRSA, CDC, and NIMH; ${ }^{25}$ these are based largely on personal relationships between agency staff. For

\footnotetext{
${ }^{22}$ The Federal/National Partnership is organized as part of the Federal Partners Senior Workgroup, made up of senior representatives of more than 20 federal agencies and offices. This Senior Workgroup is responsible for implementing the Federal Action Agenda, which focuses on efforts at the federal level to transform the mental health system. The Federal Action Agenda was developed in response to the 2003 report from the President's New Freedom Commission.

\begin{abstract}
${ }^{23}$ The federal partners include SAMHSA and other departments and agencies, such as Education, the Department of Housing and Urban Development, DOJ, the Department of Labor, the Department of Veterans Affairs, and the Social Security Administration. This partnership also includes other nongovernmental organizations working in the area of school mental health services.
\end{abstract}

\footnotetext{
${ }^{24}$ The Integration of Mental Health and Education Workgroup is also known as the School-Based Mental Health Services Workgroup. The two other workgroups are the Youth-Guided Policies and Services Workgroup and the Early Identification Workgroup.

${ }^{25}$ SAMHSA officials also maintain informal coordination efforts with HHS's Indian Health Service and Administration for Children and Families.
} 
example, at the request of Education staff, SAMHSA staff reviewed and commented on the Grants for the Integration of Schools and Mental Health Systems application before its public release. ${ }^{26}$ SAMHSA and Education officials told us they work on an as-needed basis to ensure that their respective agencies are not awarding funding to the same grantees for the same activities. SAMHSA officials told us that personnel from the two agencies also communicate with each other almost daily about the SS/HS program.

While SAMHSA and HRSA had a formal cooperative agreement in the past to co-fund two technical assistance centers for school mental health services, SAMHSA officials told us that SAMHSA is no longer providing funds for this effort, although HRSA continues to do so. ${ }^{27}$ However, the two agencies continue to have some informal interaction about the two centers. For example, SAMHSA presents an award recognizing programs that promote school mental health services at a conference hosted annually by one of these centers. In addition to this interaction, SAMHSA and HRSA staff meet on an ongoing basis to discuss how they can collaborate to assist states with efforts to integrate health, mental health, and education. For example, staff from the two agencies have met to discuss a HRSA initiative that provides funds to states to promote availability and quality of services focused on healthy child development and school readiness. The two agencies are also working together to incorporate information on the warning signs of mental health problems into an existing SAMHSA program designed to serve children with serious emotional disturbances.

SAMHSA and CDC officials also work together on an informal and episodic basis. For example, a SAMHSA official participated on an expert panel about 3 years ago to help CDC's Division of Adolescent and School Health consider how to identify possible opportunities for the division to promote and enhance the mental health component of the Coordinated School Health Program. According to CDC officials, because the agency does not have a strong focus on school mental health services, it reaches out to SAMHSA for guidance in this area. For example, CDC directs its grantees to SAMHSA's NREPP database to find appropriate interventions to implement at the local level.

SAMHSA and NIMH officials have had informal discussions on the recent redesign of SAMHSA's NREPP, and NIMH suggested researchers who could review interventions for this registry of evidence-based programs and practices. In some cases, NIMH encouraged its grantees to submit evidence-based interventions to NREPP. Staff members from the two agencies have discussed how research can be transferred into community practice, and NIMH staff have also consulted with, and provided technical assistance to, SAMHSA grantees.

\section{SAMHSA Identifies and Supports Evidence-Based Interventions, Some of Which Target School Mental Health Services}

SAMHSA identifies evidence-based mental health interventions, including some that can be used in school settings, and supports their use. To identify evidence-based mental health

\footnotetext{
${ }^{26}$ The Grants for the Integration of Schools and Mental Health Systems program provides grants to state and local education agencies and tribes for the purpose of developing linkages between school systems and local mental health systems to increase student access to quality mental health care.

${ }^{27}$ In fiscal year 2006, HRSA contributed $\$ 600,000$ to these centers, part of the Mental Health in Schools Program, while SAMHSA contributed $\$ 300,000$. HRSA contributed $\$ 900,000$ in fiscal year 2007 , but the agency has limited fiscal year 2008 funds for the program to $\$ 600,000$.
} 
interventions, SAMHSA uses its NREPP database; as of August 2007, slightly more than onefourth of the interventions on NREPP were mental health services based in schools. SAMHSA also supports the initial implementation and ongoing administration of evidence-based interventions in the school setting through grant programs, such as the SS/HS grant program. This program awards grants for evidence-based interventions and provides technical assistance for the implementation of these interventions. SAMHSA also supports the use of evidence-based interventions through other grant programs that may be used in schools but are not specifically designed for the school setting.

SAMHSA Uses a National Registry to Identify Evidence-Based Interventions, and Some Are for Use in School Settings

SAMHSA uses NREPP, a searchable online database, to help interested parties, including school officials, in identifying evidence-based interventions. ${ }^{28}$ The purpose of NREPP, which was initially designed in 1997 and redesigned in March 2007, is to help interested parties in identifying evidence-based approaches to preventing and treating mental illness and substance abuse. NREPP is funded by SAMHSA and is a core component of the agency's Science to Service Initiative, which seeks to promote broader adoption of effective, evidencebased interventions within routine clinical and community-based settings. Because there is no universally accepted definition for what constitutes evidence, SAMHSA has stated that NREPP was not designed to serve as a single authoritative source for evidence-based interventions. ${ }^{29}$ Rather, SAMHSA acknowledges that there are multiple ways of establishing and assessing the strength of an intervention's evidence, such as research methods that include pre- and posttest studies and controlled clinical studies. Agency officials characterize NREPP as one of many tools for identifying and assessing evidence-based interventions.

In order to update NREPP, SAMHSA anticipates publishing annual notices in the Federal Register soliciting evidence-based interventions that may be selected for review and placement on the registry. Interventions, submitted by those seeking placement on the NREPP registry, are evaluated through a standard process, which involves both a submission of materials and an independent review process. (See fig. 1.) The submission process is used to determine whether interventions submitted for review meet NREPP's three minimum requirements: (1) the intervention must demonstrate one or more positive outcomes, (2) the research findings related to the intervention must have been published in a comprehensive evaluation report or peer-reviewed publication, and (3) dissemination materials must be available. ${ }^{30}$

\footnotetext{
${ }^{28}$ SAMHSA redesigned NREPP (http://www.nrepp.samhsa.gov) in order to make it more comprehensive and interactive.

${ }^{29}$ See Changes to the National Registry of Evidence-based Programs and Practices, Notice, $71 \mathrm{Fed}$. Reg. (Mar. 14, 2006), and SAMHSA, "National Registry of Evidence-based Programs and Practices (NREPP): An Important Note for NREPP Users,” 2007, http://www.nrepp.samhsa.gov/about-note.htm (accessed Apr. 20, 2007).

${ }^{30}$ The positive program outcomes must be statistically significant at a level of 95 percent confidence. Dissemination materials could include items such as program manuals, program process guides, and training materials.
} 
Figure 1: NREPP Review Process

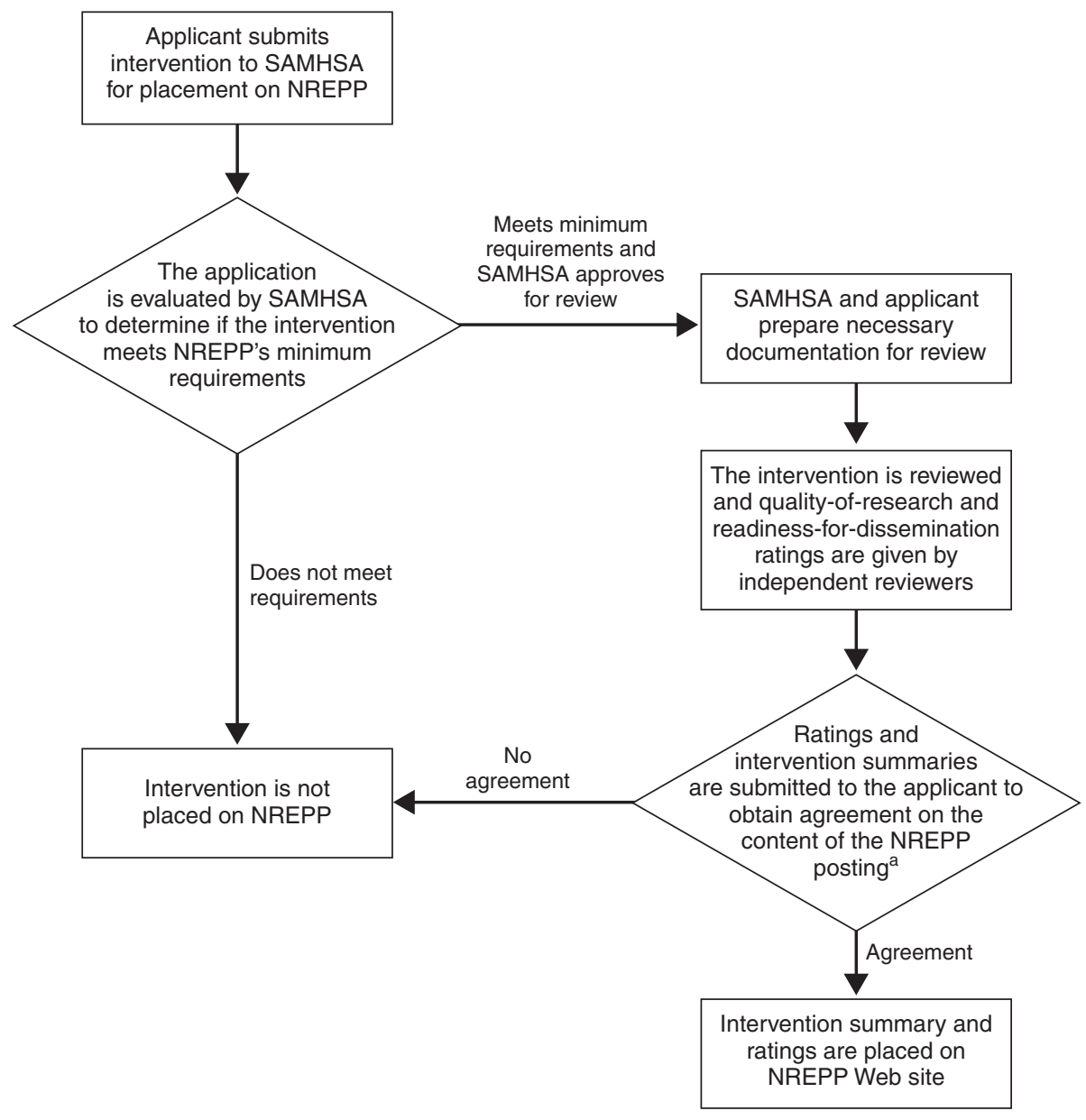

Source: GAO analysis of SAMHSA documents.

aSAMHSA provides applicants with the opportunity to approve the summary information before it is published on the Web site. However, NREPP will not change the intervention's ratings unless new information is provided by the applicant. If the applicant and SAMHSA do not agree on the Web posting (i.e., intervention summary and ratings), then the intervention will not be placed on NREPP.

Once it is determined that an intervention meets all three minimum requirements and a senior SAMHSA official approves the intervention for review, the intervention is reviewed by a panel of independent reviewers with special knowledge in the subject area. These reviewers rate the quality of the research on the intervention and its readiness for dissemination on a zero-to-four point scale. ${ }^{31}$ The quality-of-research rating is obtained by using six criteria to score the strength of the research supporting the intervention's stated

\footnotetext{
${ }^{31}$ Independent reviewers are not employed by SAMHSA; rather, they work as agency consultants to the agency's NREPP contractor. SAMHSA recruits two types of reviewers to rate each program's quality of research and readiness for dissemination. Quality-of-research reviewers must have a doctoral-level degree and, if possible, possess experience evaluating prevention and treatment programs. Readinessfor-dissemination reviewers can include consumers of services, service providers, and experts in program implementation. Both types of reviewers must possess knowledge of mental health and/or substance use prevention or treatment content areas.
} 
outcomes, and then averaging the six ratings. ${ }^{32}$ The readiness-for-dissemination rating is achieved by evaluating the dissemination materials using three criteria and averaging the ratings of these criteria. ${ }^{33} \mathrm{~A}$ final rating for the intervention's quality of research and readiness for dissemination is achieved by reaching reviewer consensus if there are significant differences in their ratings. SAMHSA posts the intervention's ratings on its Web site along with additional descriptive information on the intervention. ${ }^{34}$ (See fig. 2 for a sample NREPP rating.)

Figure 2: Sample NREPP Rating

Quality-of-research ratings by criteria ( $0.0-4.0$ scale)

\begin{tabular}{|c|c|c|c|c|c|c|c|}
\hline \multicolumn{8}{|l|}{ Outcome } \\
\hline $\begin{array}{c}\text { Outcome 1: School disciplinary } \\
\text { code violations }\end{array}$ & 1.0 & 2.5 & 2.3 & 2.0 & 2.3 & 3.5 & 2.3 \\
\hline $\begin{array}{r}\text { Outcome 2: Violent/aggressive } \\
\text { behavior-self-reports }\end{array}$ & 2.5 & 2.5 & 2.3 & 2.0 & 2.3 & 3.5 & 2.5 \\
\hline Outcome 3: Victimization & 2.5 & 2.5 & 2.0 & 2.0 & 2.5 & 3.5 & 2.5 \\
\hline Outcome 4: Peer provocation & 2.5 & 2.5 & 2.0 & 2.0 & 2.3 & 3.3 & 2.4 \\
\hline Outcome 5: Life satisfaction & 2.5 & 2.5 & 2.0 & 2.0 & 2.5 & 3.5 & 2.5 \\
\hline
\end{tabular}

Readiness-for-dissemination ratings by criteria ( $0.0-4.0$ scale)

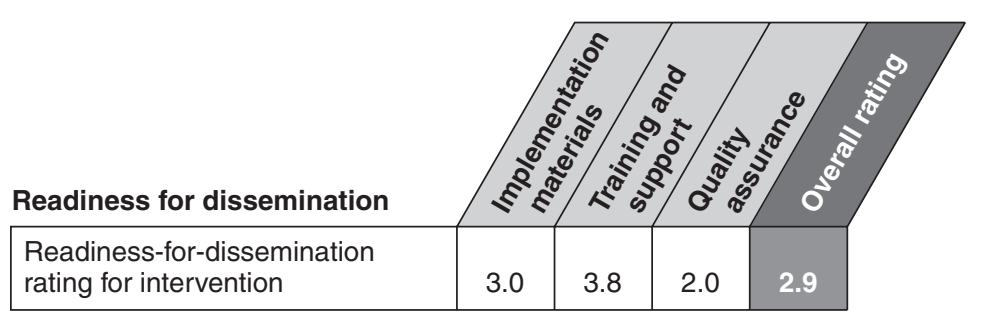

Source: NREPP.

Note: Listed outcomes are examples.

${ }^{32}$ Each program outcome is evaluated by reviewing the following six "quality-of-research" criteria: (1) reliability of the outcome measures, (2) validity of the outcome measures, (3) intervention fidelity - the "experimental" intervention was implemented as designed, (4) missing data and attrition, (5) potential confounding variables, and (6) appropriateness of the analysis.

${ }^{33}$ The three "readiness-for-dissemination" criteria are evaluated by reviewing the amount and adequacy of the intervention's (1) implementation materials, (2) training supports, and (3) quality improvement materials, such as manuals on how to provide quality improvement feedback.

${ }^{34}$ Prior to the 2007 redesign of NREPP, programs were rated in their entirety by placing them into three categories of effectiveness: model, effective, and promising. According to SAMHSA officials, the agency chose to eliminate these categories because they appeared arbitrary to some users and distinctions between them were unclear. The agency plans to advertise these changes through several efforts, such as e-mail alerts to notify users when new programs have been added to the registry. 
Some interventions listed on NREPP were designed for use in the school setting. Specifically, as of August 2007, 13 of NREPP's 46 interventions were identified as school mental health interventions, including those designed to address aggressive behavior, depression, or school violence. Other settings for interventions listed on NREPP include correctional facilities, residential settings, and the workplace. SAMHSA is in the process of adding interventions to the registry and, according to a SAMHSA official, approximately half of the intervention applications submitted in fiscal year 2007 were mental health or substance abuse interventions that could be appropriate for use in schools.

SAMHSA Supports Evidence-Based Mental Health Interventions That Can Be Used in School $\underline{\text { Settings }}$

SAMHSA supports the use of evidence-based interventions in the school setting in the SS/HS grant program. SS/HS program policy requires that grantees implement and administer evidence-based interventions, but does not require its grantees to use a specific method of selecting those interventions. ${ }^{35}$ The program's grant application provides potential grantees with guidance on how to choose an evidence-based intervention and with a list of online resources, including NREPP. To help current grantees identify and implement evidencebased interventions, the National Center for Mental Health Promotion and Youth Violence Prevention provides technical assistance to all active SS/HS grantees through a cooperative agreement with SAMHSA. The National Center also provides current grantees with additional technical assistance, such as support in implementing culturally appropriate programs or designing and implementing program evaluation tools.

SAMHSA also supports the use of evidence-based mental health interventions when funding other programs that may be used in schools or community settings. SAMHSA's Child Mental Health Initiative provides federal funds, through cooperative agreements with state and local governments and tribal organizations, to develop and sustain an effective system of care for children with serious emotional disturbances. The funding recipients are required to collaborate with other entities that serve children, such as local child welfare and juvenile justice agencies. In fiscal years 2005 and 2006, most federal funding for the program was directly provided to, and managed by, state and local governments. Child Mental Health Initiative recipients may use the funds to provide mental health interventions in schools and are required by SAMHSA policy to implement at least one evidence-based intervention. However, according to a SAMHSA official, funding recipients have noted that it can be challenging for those outside schools to work within a school setting. Another program, SAMHSA's State/Tribal Youth Suicide Prevention Grant Program, provides funds through cooperative agreements with states, tribal communities, and public or nonprofit organizations to support the development and implementation of statewide or tribal youth suicide prevention and intervention strategies. Preference is given to program participants that collaborate with institutions that serve youth, which could include schools, and SAMHSA policy requires program participants to report the number of evidence-based interventions used.

\footnotetext{
${ }^{35}$ The SS/HS program defines an evidence-based intervention as one that is supported by scientific data to indicate its effectiveness. The statutes authorizing SAMHSA, Education, and DOJ's programs do not require that grantees implement evidence-based programs. 20 U.S.C. $§ 7131 ; 42$ U.S.C. $\S \S 290 \mathrm{hh}, 5614$. The requirement is set forth in program selection criteria developed by the agencies responsible for the SS/HS program and published as a Notice of Final Priorities, Requirements, Selection Criteria, and Definitions in the Federal Register.
} 


\section{Multiple Factors Affect the Provision of School Mental Health Services}

Officials in the seven schools and school districts in our review told us that coordination and close working relationships, support from program champions-advocates for a programand school leadership, and resources are factors that can affect the provision of school mental health services. Because the missions of mental health and education professionals differ, coordination between them can enhance the provision of school mental health services. Coordination with external stakeholders (such as community mental health providers) and among internal stakeholders (such as teachers and health care professionals) can also affect the provision of school mental health services. Site officials stressed that one or more program champions and support from school leaders can play a significant role in implementing school mental health services; conversely, the loss of either of these can threaten program continuity. Site officials also noted that difficulties securing and sustaining both funding and staffing have affected the ability to implement school mental health services.

\section{Differing Missions and Coordination of Efforts Affect Service Provision}

Because the missions of mental health and education professionals differ, coordination between them can enhance the provision of school mental health services, according to experts and school staff. While mental health providers typically focus on the emotional health of students, the primary focus of schools is students' academic achievement. By framing student mental health as a means of improving student academic achievement, experts told us that mental health providers may improve the likelihood of being able to implement a school program. School officials we interviewed, including principals and teachers, said they recognized that addressing students' social, emotional, and behavioral health needs can improve their ability to focus on academics. The principal of one school reported that, in the past, her teachers spent a large amount of their time dealing with nonacademic issues, including behavioral problems, in the classroom. This school now provides universal mental health services for all students and selective services for a smaller subset of students. For example, the school offers a schoolwide program to reduce student aggression and behavior problems, and also works with community mental health providers to obtain services for children with more serious needs. Teachers said that because of these efforts, disruptions associated with students' behavioral issues have been reduced and they are better able to focus on academics.

Site officials told us that to provide services in the school setting, mental health professionals need to be cognizant not only of a school's academic mission, but also of students' academic schedules and responsibilities. Staff members at one site reported that they avoided scheduling appointments for services during school testing periods, while staff from another reported that they tried to provide as many services as possible during nonacademic times, such as lunch. Some school officials noted that working with external providers could pose difficulties because these providers might not recognize the priority of the school's academic schedule. An official from one site with multiple school-based health centers stated that a past contract it had with a community provider to run one of its centers was terminated because the provider was not able to work within the schedule constraints of the school.

Site officials told us that coordinating with external stakeholders-local government agencies, providers, or community organizations-is important when implementing school mental health services. Two sites in one state partner with county councils made up of 
multiple local agencies serving children and families. ${ }^{36}$ Staff from these two sites reported that the partnership helped them establish a relationship with other agencies, such as juvenile justice or job and family service agencies, that may influence the lives of their students. A representative from one of the county councils stated that prior to the council's work with school officials, agencies in the county had been interested in working with schools but did not know how to bring that about. Officials at some sites told us they also had developed relationships with local religious organizations. At one site, officials reported that this resulted in the organizations' supporting after-school and summer activities and acting as a source of volunteers to help organize these events when needed. Officials from sites in our review also told us that family involvement in the services provided to children was an important factor and that they typically required parental consent for students to receive services.

In addition, staff at sites in our review emphasized the importance of working closely with existing school health and mental health staff-including counselors, social workers, psychologists, and nurses - to ensure the success of school mental health services. They noted that it was particularly important to work together when implementing initiatives, in order to reduce service overlap or potential conflict between providers. In schools with a school-based health center, officials reported that the school nurse often worked in collaboration with the centers, providing care to students not enrolled in the center or identifying enrolled students in need of services. ${ }^{37}$ In one school without a school-based health center, the school nurse and the school social worker who coordinates the universal mental health programs meet regularly to discuss students referred for physical and mental health problems. Officials at sites in our review also noted that school nurses may help identify when students who come in for physical health reasons may have symptoms related to mental health issues. Officials told us that, in some cases, failure to recognize the roles of existing school staff members had created tension.

Sites also work to include teachers and administrative staff in their school or school district programs and to provide teachers with training or materials on mental health issues. Two sites have developed multidisciplinary teams, including teachers and school administrators as well as mental health professionals, that meet to identify and coordinate services for students showing signs of mental health problems. By including teachers and school administrators in efforts, sites try to ensure that all staff members are involved in the program. Officials from one of these sites also reported providing training to teachers on a variety of issues, including understanding mental health diagnoses, the impact of trauma on children, and nonacademic barriers to learning, such as issues related to poverty. Staff members at a third site have created documents for teachers, including handouts providing information on when to refer students for mental health services, the protocol for referrals, and the role of case managers.

\footnotetext{
${ }^{36}$ This state has developed an initiative that includes both state- and county-level partnerships focused on improving the well-being of children and their families. The partnerships are composed of government agencies, and, at the county level, also include community organizations. County-level councils, formed by the county board of commissioners, must include representation from families, schools, and multiple agencies, including alcohol, drug addiction, mental health, and job and family services.

${ }^{37}$ Eligible students who wish to receive services through the school-based health center at the sites we reviewed are required to join the center by enrolling.
} 


\section{Program Champions and School Leadership Affect Provision of Services}

Officials at sites in our review stressed the importance of having a program champion and the support of school and school district leadership when implementing programs. At one site, officials stated that their effort to introduce a school mental health services program had multiple champions, including staff from the local educational service center ${ }^{38}$ and local mental health providers. Officials at this site reported bringing together community agencies that work with children, including local school districts, and said that they were able to hire a program director who, according to site staff, had the "passion" to run the program. The staff from the multiple agencies involved believed that without this program director to further champion the program, they would not have been able to continue to dedicate sufficient attention to the program to keep it moving forward. At another site, officials told us that the principal was the champion for mental health services at the school and provided the school leadership needed to implement programs. Because of the success of efforts at that school, the superintendent of the district asked this principal to examine how services could be expanded to another district school.

Officials we spoke with told us, however, that initiatives may become dependent on the program champion and expressed concern that such initiatives might not be able to survive the champion's departure. Similarly, officials told us that wavering support at the administrative level or a change in leadership — particularly principals and superintendentscould raise concerns for program sustainability. In one school district, staff told us that while the indicated mental health services provided through their school-based health centers were well established, the universal mental health initiatives they had implemented, such as a classroom-based violence prevention program, would not have existed without the leadership of one particular staff member. The person identified as the program champion told us that she would like to train a successor but, because of budget constraints, it would be difficult to hire a new staff person to train while she was still in her position. Officials at another site told us their program champion was the school principal, who planned to retire in 3 years. To ensure that the existing mental health initiatives continue, the principal was working to fully train school staff, including teachers, to maintain and advocate for these initiatives. Because staff from this school will be involved in the process of hiring a replacement, the current principal hopes that they will be in a position to identify a potential replacement who will continue the initiatives.

\section{Securing and Sustaining Funding and Appropriate Staff for School Mental Health Services Affect Service Provision}

Site officials told us that difficulty securing and sustaining funding and mental health service provider staff had affected their ability to implement school mental health services. According to experts, no single funding stream specifically focuses on school mental health services, and sites reported piecing together multiple funding streams to support their programs. For example, officials at one site reported combining funds from at least four different sources, including private grants, the state Department of Education, and federal

\footnotetext{
${ }^{38}$ This center provides services, including technical and operational assistance, professional development, and curriculum services, to the eight school districts within its area.
} 
sources, to support its mental health services. ${ }^{39}$ Officials at this site said that while their school district provided space for service delivery, it provided no monetary support for the site's programs. Funding streams that staff identified often came with restrictions on use. For example, one site provided case management services to students, but because of funding restrictions, these services could be provided only to elementary students who qualified for free and reduced lunches. ${ }^{40}$ Officials stated that Medicaid, while a possible funding source for some services, was difficult to use. In particular, they expressed concerns related to Medicaid's paperwork, reimbursement rates, and enrollment of eligible students in the Medicaid program. In addition, changes in funding priorities can affect sites' funding for programs. At the time of our site visits, two sites in one state told us they had just been notified that state-level funding priorities had shifted. As a result, these sites anticipated laying off, or cutting the hours of, case management or mental health staff. ${ }^{41}$

Officials at the sites in our review said they appreciated the flexibility of grant funding, but said that grants might not last long enough to allow a program to stabilize and that other funds to sustain initiatives were not always available. ${ }^{42}$ Officials from one site, located in a town surrounded by rural counties, noted that while grants often required them to consider sustainability when applying for funds, the school district and county had no funds to support initiatives started through grants and they were not aware of local foundations or organizations that might be able to provide additional funds.

While officials indicated that it was difficult to secure funding, some reported that by coordinating the efforts of multiple local agencies or securing the support of the school administrator, they were able to identify resources to support their programs. By partnering with local government agencies and other stakeholders, staff from one site were able to use resources available to those organizations, including resources that might not otherwise be available to schools. In addition, relationships with external agencies helped create advocates in the community for another school district's program, according to officials. At another site, officials reported that while they had not formally secured funding for the staff needed to continue a grant program, the principals of some schools participating in the program said they were willing to include the salary of the schools' program staff members in

\footnotetext{
${ }^{39}$ The federal funds came from Medicaid and the Temporary Assistance for Needy Families (TANF) program, which provides funds to states to provide assistance and work opportunities to needy families. Both federal and state governments contribute to Medicaid and TANF.

${ }^{40}$ For elementary students who did not qualify for services, this site used its prevention coordinator-a grant-funded contractor responsible for schoolwide prevention activities - to provide limited individual assistance. However, an official at this site noted that restrictions limiting services to only certain populations, such as students in certain grades or at certain income levels, could lead to resentment over services not being available to all students.

${ }^{41}$ Officials in one of these school districts reported that with 2 weeks left before the end of the school year, they had not been told whether they would have funds to retain their case management staff for the upcoming school year. As of August 2007, all case management positions had been eliminated, and this site was no longer offering case management services.

${ }^{42}$ An official from one site also told us that funding streams may not be consistent, noting that funding that may have been available 2 or 3 years before may no longer be available.
} 
their general school budgets for the upcoming year. One principal told us that she was willing to do this because the program was an asset to the school. ${ }^{43}$

Site officials told us that, in addition to securing and sustaining funding, it could be difficult to hire and retain mental health professionals to provide school services, particularly in small towns and rural areas. Providers at one site noted that the site's program could expand only to a limited degree because there were no more available mental health providers in the area. ${ }^{44}$ Staff reported difficulty recruiting providers to the area, a town located about 1 hour from a metropolitan area where mental health providers are paid significantly more. Staff members from a rural school district similarly told us that they had been trying to hire a behavioral health specialist since October 2006 but had not been able to find one willing to move to their district until June 2007.

Contrary to the experience of some sites, schools and school districts located near universities reported having better access to providers. Officials from one urban school district reported working with local universities to offer internship opportunities, which allowed it to attract former interns to positions as permanent staff. At another site, which has had difficulties attracting mental health staff, providers involved in the program are working with a local university to expand the university's social work program, and hope this expansion will be a source of future mental health staff.

\section{Agency Comments}

We provided a draft of this report to HHS and Education for comment. HHS provided written comments on the draft of this report, which are provided in enclosure IV. HHS also provided technical comments, which we incorporated where appropriate. HHS indicated that the report accurately reflects SAMHSA's efforts regarding school mental health services. The agency also stressed the importance of schools as a venue for the delivery of mental health prevention and treatment programs, services, and supports. Education told us it had no comments on the draft.

As we agreed with your office, unless you publicly announce the contents of this report earlier, we plan no further distribution of this letter until 30 days after the date of this letter. At that time, we will send copies to the Administrator of SAMHSA, appropriate congressional committees, and other interested parties. In addition, the report will be available at no charge on the GAO Web site at http://www.gao.gov. If you or your staff have any questions about this report, please contact me at (202) 512-7114 or bascettac@gao.gov. Contact points for our

\footnotetext{
${ }^{43}$ School officials noted that these individual school budgets require approval at the superintendent level, so these positions could still be cut. As of June 2007, staff and school officials did not know whether these positions would be approved for the 2007-2008 school year.

${ }^{44}$ Staff at this site told us that they were willing to use a variety of mental health provider types, although they preferred to use master's-level counselors. Officials from other sites also indicated that they were willing to use, and had used, a variety of mental health provider types including social workers, counselors, and marriage and family therapists.
} 
Offices of Congressional Relations and Public Affairs may be found on the last page of this report. GAO staff who made major contributions to this report are listed in enclosure V.

Sincerely yours,

$$
\begin{gathered}
\text { Cynthia Bascutu } \\
\text { Cynthia A. Bascetta } \\
\text { Director, Health Care }
\end{gathered}
$$




\section{Enclosure I}

\section{Scope and Methodology}

We examined the Substance Abuse and Mental Health Services Administration's (SAMHSA) efforts to coordinate with federal departments and agencies to support school mental health services and to identify and support evidence-based school mental health services. ${ }^{45}$ To do this, we reviewed multiple documents, including a collaborative agreement related to federal school mental health funding, interagency meeting minutes, documents describing changes in the National Registry of Evidence-based Programs and Practices (NREPP), and Federal Register notices. We interviewed staff at SAMHSA, including program staff charged with implementing interagency programs related to children's mental health and developing and implementing NREPP. We also interviewed staff from the Department of Health and Human Services' Health Resources and Services Administration, Centers for Disease Control and Prevention, and National Institutes of Health. We spoke with staff from the Department of Justice and the Department of Education who interact with SAMHSA with regard to school mental health.

To describe factors that have affected the provision of school mental health services, we reviewed relevant research and interviewed experts working in the area of school mental health, including representatives of the Center for Health and Health Care in Schools, Center for Mental Health in Schools, Center for School Mental Health Analysis and Action, Center for School-Based Mental Health Programs, Research and Training Center for Children's Mental Health, and National Assembly on School-Based Health Care. To obtain information on their constituents' roles in school settings, we also reviewed documents and interviewed representatives from professional associations whose members provide school mental health services, including the National Association of School Psychologists, American School Counselor Association, School Social Work Association of America, National Association of School Nurses, and the American Association for Marriage and Family Therapy. In addition, we interviewed officials with associations representing education service providers, such as the American Association of School Administrators and the National School Boards Association.

To provide information on factors that selected sites considered important when providing school mental health services, we conducted interviews with representatives from seven selected schools and school districts. To identify states, localities, specific schools, and school districts considered to be active in the area of school mental health services, we interviewed officials from federal agencies, experts in the area of school mental health, and provider associations. From the approximately 53 locations they identified, we selected a judgmental sample of 7 sites: two school districts in Connecticut, one school district in Florida, one multidistrict program in North Carolina, and one school district, one school, and one multidistrict program in Ohio. These sites were selected because they represented a mix of urban and rural settings and settings with and without school-based health centers. We also ensured that we included sites that were currently receiving funds through the joint SAMHSA, Department of Education, and Department of Justice Safe Schools/Healthy Students program and the Department of Education Grants for the Integration of Schools and Mental Health Systems program. Because we used a nongeneralizable sample to select our sites, the information provided cannot be used to make inferences about other programs. In

\footnotetext{
${ }^{45}$ School mental health services provided to students who qualify for special education services through the Individuals with Disabilities Education Act were outside the scope of our work.
} 


\section{Enclosure I}

addition, the information provided by program officials does not reflect all efforts under way in their locations related to school mental health services.

We conducted our work from March 2007 through September 2007 in accordance with generally accepted government auditing standards. 


\section{Enclosure II}

\section{Characteristics of Sites in Our Review}

\begin{tabular}{|c|c|c|c|c|c|c|}
\hline State & $\begin{array}{l}\text { Location } \\
\text { characteristics }\end{array}$ & $\begin{array}{l}\text { School } \\
\text { district size }^{a}\end{array}$ & $\begin{array}{l}\text { School or } \\
\text { school } \\
\text { district } \\
\text { population }\end{array}$ & $\begin{array}{l}\text { Safe } \\
\text { Schools/ } \\
\text { Healthy } \\
\text { Students } \\
\text { grantee }\end{array}$ & $\begin{array}{l}\text { School- } \\
\text { based } \\
\text { health } \\
\text { center }\end{array}$ & Program description \\
\hline \multirow[t]{2}{*}{ Connecticut } & $\begin{array}{l}\text { School district } \\
\text { located in an } \\
\text { urban area }\end{array}$ & $\begin{array}{l}\text { The school } \\
\text { district consists } \\
\text { of } 41 \text { schools }\end{array}$ & $\begin{array}{l}22,296 \\
\text { students in } \\
\text { the school } \\
\text { district }\end{array}$ & Yes & Yes & $\begin{array}{l}\text { The school district provides } \\
\text { universal services throughout } \\
\text { the district using an evidence- } \\
\text { based program that has been } \\
\text { in place for several years. This } \\
\text { school district also provides a } \\
\text { variety of selective and } \\
\text { indicated services to students } \\
\text { through its multiple school- } \\
\text { based health centers. }\end{array}$ \\
\hline & & & & & & $\begin{array}{l}\text { To assist students in need of } \\
\text { more intensive support, such } \\
\text { as therapy services, the district } \\
\text { works with a community } \\
\text { mental health provider; through } \\
\text { the Safe Schools/Healthy } \\
\text { Students (SS/HS) Initiative, it } \\
\text { has also been able to secure } \\
\text { funding for a child psychiatrist. } \\
\text { Students in certain high } \\
\text { schools also receive services } \\
\text { through centers, staffed in } \\
\text { large part by master's-level } \\
\text { social work interns, designed } \\
\text { to provide counseling and } \\
\text { support to students and their } \\
\text { families. These centers are } \\
\text { part of the district's SS/HS } \\
\text { Initiative. }\end{array}$ \\
\hline Connecticut & $\begin{array}{l}\text { School district } \\
\text { located in an } \\
\text { urban area }\end{array}$ & $\begin{array}{l}\text { The school } \\
\text { district consists } \\
\text { of } 35 \text { schools }\end{array}$ & $\begin{array}{l}22,264 \\
\text { students in } \\
\text { the school } \\
\text { district }\end{array}$ & No & Yes & $\begin{array}{l}\text { Universal mental health } \\
\text { services, including violence } \\
\text { and bullying prevention, are } \\
\text { provided using multiple } \\
\text { evidence-based programs. } \\
\text { Mental health services at both } \\
\text { the selective and the indicated } \\
\text { level are provided to regular } \\
\text { education students through } \\
\text { multiple school-based health } \\
\text { centers. The centers are } \\
\text { staffed by mental health } \\
\text { providers, including social } \\
\text { workers. For students needing } \\
\text { more intensive services or to } \\
\text { respond to crisis situations, the } \\
\text { centers also have psychiatric } \\
\text { staff on call. }\end{array}$ \\
\hline
\end{tabular}




\section{Enclosure II}

\begin{tabular}{|c|c|c|c|c|c|c|}
\hline State & $\begin{array}{l}\text { Location } \\
\text { characteristics }\end{array}$ & $\begin{array}{l}\text { School } \\
\text { district size }^{a}\end{array}$ & $\begin{array}{l}\text { School or } \\
\text { school } \\
\text { district } \\
\text { population }^{\mathrm{a}}\end{array}$ & $\begin{array}{l}\text { Safe } \\
\text { Schools/ } \\
\text { Healthy } \\
\text { Students } \\
\text { grantee }\end{array}$ & $\begin{array}{l}\text { School- } \\
\text { based } \\
\text { health } \\
\text { center }\end{array}$ & Program description \\
\hline Florida & $\begin{array}{l}\text { School district } \\
\text { located in a } \\
\text { rural county }\end{array}$ & $\begin{array}{l}\text { The school } \\
\text { district consists } \\
\text { of } 2 \text { schools }^{b}\end{array}$ & $\begin{array}{l}1,058 \\
\text { students in } \\
\text { the school } \\
\text { district }^{\mathrm{b}}\end{array}$ & Yes & No & $\begin{array}{l}\text { This school district provides } \\
\text { universal services, including a } \\
\text { bullying prevention program, } \\
\text { after-school activities, and drug } \\
\text { and alcohol prevention } \\
\text { activities. A counselor is } \\
\text { available to provide mental } \\
\text { health services to students } \\
\text { across the district. The school } \\
\text { district works with a private } \\
\text { contractor to provide more } \\
\text { intensive services, such as } \\
\text { therapy, to students who need } \\
\text { them. The district also partners } \\
\text { with the state health } \\
\text { department and local agencies } \\
\text { serving children as part of the } \\
\text { SS/HS Initiative. }\end{array}$ \\
\hline $\begin{array}{l}\text { North } \\
\text { Carolina }\end{array}$ & $\begin{array}{l}\text { Regional } \\
\text { grouping of } \\
\text { school districts } \\
\text { located in } 3 \\
\text { rural counties }\end{array}$ & $\begin{array}{l}\text { The regional } \\
\text { grouping } \\
\text { consists of } 3 \\
\text { school districts } \\
\text { with } 21 \\
\text { schools }^{c}\end{array}$ & $\begin{array}{l}7,014 \\
\text { students in } \\
\text { the combined } \\
3 \text { school } \\
\text { districts }^{\circ}\end{array}$ & Yes & Yes & $\begin{array}{l}\text { The districts have implemented } \\
\text { universal services for students, } \\
\text { including a violence and drug } \\
\text { abuse prevention program, } \\
\text { and are conducting training for } \\
\text { teachers and administrators on } \\
\text { mental health issues. Using } \\
\text { funds from the SS/HS } \\
\text { Initiative, three school districts } \\
\text { are implementing school } \\
\text { nurse-school counselor teams } \\
\text { in schools throughout their } \\
\text { districts. These teams act as } \\
\text { the initial contact for students } \\
\text { in need of selective or } \\
\text { indicated mental health } \\
\text { services and work in } \\
\text { coordination with community } \\
\text { providers to secure services } \\
\text { for students. In addition, the } \\
\text { districts have developed a } \\
\text { council of key agencies and } \\
\text { organizations that may impact } \\
\text { students' lives. }\end{array}$ \\
\hline Ohio & $\begin{array}{l}\text { Regional } \\
\text { grouping of } \\
\text { school districts } \\
\text { in and around a } \\
\text { small town }\end{array}$ & $\begin{array}{l}\text { The regional } \\
\text { grouping } \\
\text { consists of } 8 \\
\text { school districts } \\
\text { with } 43 \text { schools }\end{array}$ & $\begin{array}{l}18,193 \\
\text { students in } \\
\text { the combined } \\
8 \text { school } \\
\text { districts }\end{array}$ & No & No & $\begin{array}{l}\text { This regional effort focuses on } \\
\text { providing services through } \\
\text { multidisciplinary teams. These } \\
\text { teams can include school } \\
\text { administrators and teachers, } \\
\text { staff from local community } \\
\text { mental health providers, } \\
\text { substance abuse } \\
\text { professionals, and staff from } \\
\text { the local health department } \\
\text { and juvenile court. The } \\
\text { composition of the teams } \\
\text { varies by school, and others } \\
\text { may be invited to participate as } \\
\text { needed. }\end{array}$ \\
\hline
\end{tabular}




\section{Enclosure II}

\begin{tabular}{|c|c|c|c|c|c|}
\hline State & $\begin{array}{l}\text { Location } \\
\text { characteristics }\end{array}$ & $\begin{array}{l}\text { School } \\
\text { district size }\end{array}$ & $\begin{array}{l}\text { School or } \\
\text { school } \\
\text { district } \\
\text { population }\end{array}$ & $\begin{array}{l}\text { Safe } \\
\text { Schools/ } \\
\text { Healthy } \\
\text { Students } \\
\text { grantee }\end{array}$ & $\begin{array}{l}\text { School- } \\
\text { based } \\
\text { health } \\
\text { center }\end{array}$ \\
\hline
\end{tabular}

(cont'd.)

Program description

The teams provide services at the universal, selective, and indicated level. They build a complete system of services for students and their families based in a school setting, and include an after-school component, skill/asset building, mentoring, and counseling services.

\begin{tabular}{lllll}
\hline Ohio & $\begin{array}{l}\text { Single school } \\
\text { within the }\end{array}$ & $\begin{array}{l}\text { The school is } 370 \text { students } \\
\text { part of a school in the school }\end{array}$ & & No \\
school district of & district with 12 & & \\
a midsize town & schools & &
\end{tabular}

This elementary school works with community partners, including local government agencies and nonprofits, to provide universal, selective, and indicated services. It provides universal services through an evidence-based classroom program and uses the combined services of a school nurse and school social worker to provide selective services to children in need of additional support. If students need intensive services, the school works with a local mental health provider to obtain services. This same provider also offers case management support for the school.

\begin{tabular}{|c|c|c|c|c|c|c|}
\hline Ohio & $\begin{array}{l}\text { School district in } \\
\text { a small urban } \\
\text { jurisdiction co- } \\
\text { located with a } \\
\text { large urban area }\end{array}$ & $\begin{array}{l}\text { The school } \\
\text { district consists } \\
\text { of } 3 \text { schools }\end{array}$ & $\begin{array}{l}1,098 \\
\text { students in } \\
\text { the school } \\
\text { district }\end{array}$ & No & Yes & $\begin{array}{l}\text { This school district includes a } \\
\text { school-based health center } \\
\text { and provides a variety of } \\
\text { mental health services to } \\
\text { elementary and middle school } \\
\text { students. Universal services } \\
\text { are provided at the district's } \\
\text { two elementary schools using } \\
\text { two evidence-based programs } \\
\text { identified through the } \\
\text { Substance Abuse and Mental } \\
\text { Health Services } \\
\text { Administration. One of these } \\
\text { programs is also used to } \\
\text { provide services to students at } \\
\text { the district's middle school. } \\
\text { These services are } \\
\text { implemented by a contracted } \\
\text { prevention coordinator (a } \\
\text { licensed mental health } \\
\text { provider) and a doctoral intern } \\
\text { from an area university. }\end{array}$ \\
\hline
\end{tabular}




\section{Enclosure II}

\begin{tabular}{|c|c|c|c|c|c|c|}
\hline State & $\begin{array}{l}\text { Location } \\
\text { characteristics }\end{array}$ & $\begin{array}{l}\text { School } \\
\text { district size }\end{array}$ & $\begin{array}{l}\text { School or } \\
\text { school } \\
\text { district } \\
\text { population }\end{array}$ & $\begin{array}{l}\text { Safe } \\
\text { Schools/ } \\
\text { Healthy } \\
\text { Students } \\
\text { grantee }\end{array}$ & $\begin{array}{l}\text { School- } \\
\text { based } \\
\text { health } \\
\text { center }\end{array}$ & Program description \\
\hline $\begin{array}{l}\text { Ohio } \\
\text { (cont'd.) }\end{array}$ & & & & & & $\begin{array}{l}\text { Selective and indicated } \\
\text { services, including limited } \\
\text { therapy and case management } \\
\text { services, are provided by staff } \\
\text { from the school-based health } \\
\text { center and through a contract } \\
\text { with a community-based } \\
\text { mental health provider. The } \\
\text { school-based health center is } \\
\text { supported by a pediatrician } \\
\text { who can assist in the referral of } \\
\text { children in need of mental } \\
\text { health services to outside } \\
\text { providers. }\end{array}$ \\
\hline
\end{tabular}

Source: GAO analysis of information from sites and U.S. Department of Education.

Note: Universal services are those intended for all children; selective services are those targeting a smaller subset of children, usually those identified as at-risk for developing mental health problems; indicated services are those targeting children with the greatest need of support.

annless otherwise noted, data are for the 2004-2005 school year for public schools.

${ }^{\mathrm{b}}$ Officials at this site reported that the school district also provides services to the one local private school in its district, which has about 100 students.

${ }^{\mathrm{c}}$ These data are for the $2005-2006$ school year for public schools.

${ }^{\mathrm{d}}$ The total school district population was 4,994 students. 


\title{
Enclosure III
}

\author{
Information on the Safe Schools / Healthy Students Grant Program, as of \\ August 2007
}

\begin{tabular}{ll}
\hline $\begin{array}{l}\text { Participating } \\
\text { agencies and } \\
\text { offices }\end{array}$ & $\begin{array}{l}\text { Office of Safe and Drug-Free Schools within the Department of Education, Substance } \\
\text { Abuse and Mental Health Services Administration (SAMHSA) within the Department } \\
\text { of Health and Human Services (HHS), and Office of Juvenile Justice and } \\
\text { Delinquency Prevention within the Department of Justice }\end{array}$ \\
\hline Type of assistance & Discretionary/Competitive Grant \\
\hline Who can apply & Local Educational Agencies (LEAs) \\
\hline Program description & $\begin{array}{l}\text { Safe Schools/Healthy Students (SS/HS) grants support LEAs in the development of } \\
\text { communitywide approaches to creating safe and drug-free schools and promoting } \\
\text { healthy childhood development. Programs are intended to prevent violence and the } \\
\text { illegal use of drugs and to promote safety and discipline. LEAs are required to partner } \\
\text { with local law enforcement, public mental health, and juvenile justice agencies. This } \\
\text { program has been jointly funded and administered by HHS and the Departments of }\end{array}$ \\
& $\begin{array}{l}\text { Education and Justice. Within HHS, SAMHSA has primary responsibility for this } \\
\text { program. }\end{array}$ \\
\hline $\begin{array}{l}\text { Maximum grantee } \\
\text { awards }\end{array}$ & $\begin{array}{l}\$ 2,250,000 \text { per year for 4 years for an LEA with at least 35,000 students } \\
\text { - } \$ 1,500,000 \text { per year for } 4 \text { years for an LEA with at least 5,000 students but fewer } \\
\text { than 35,000 students }\end{array}$ \\
- $\$ 750,000$ per year for 4 years for an LEA with fewer than 5,000 students
\end{tabular}

\begin{tabular}{ll}
\hline Education level & Kindergarten through 12th grade $^{c}$ \\
\hline $\begin{array}{l}\text { New SS/HS awards, } \\
\text { by fiscal year }\end{array}$ & Fiscal year 2007: $\$ 37,454,964$ \\
& Fiscal year 2006: $\$ 30,913,344$ \\
& Fiscal year 2005: $\$ 76,367,807$
\end{tabular}

Legislative citation Public Health Service Act, as amended, § 581, 42 U.S.C. § 290hh Juvenile Justice and Delinquency Prevention Act, as amended, § 204, 42 U.S.C. § 5614

Elementary and Secondary Education Act of 1965, as amended, Title IV, Part A, Subpart 2, § 4121; 20 U.S.C. § 7131

Number of new
awards, by federal
fiscal year

Program elements
Fiscal year 2007: 27 awards

Fiscal year 2006: 19 awards

Fiscal year 2005: 40 awards

- Safe school environments and violence prevention activities: Support a continuum of strategies-including universal prevention, early intervention, and intensive activities, curricula, programs, and services-focused on the entire school population as well as students with disruptive, destructive, or violent behaviors.

- Alcohol, tobacco, and other drug prevention activities: Support the prevention or reduction of substance use and abuse among youth, in coordination with broader environmental strategies that address change at the individual, classroom, school, family, and community level.

- Student behavioral, social, and emotional supports: Support strategies to promote positive relationships for youth and meaningful parental and community involvement, and to recognize the role of students' social and emotional needs in their development.

- Mental health services: Support enhanced integration, coordination, and resource sharing among education, mental health, and social service providers, including early identification and assessment and providing early intervention services for atrisk children and their families, and referral and follow-up with local public mental health agencies as needed. Also support school staff training and consultation, supportive services to families, and revision of policies and procedures to address communication and sharing of information across service systems. 


\section{Enclosure III}

\begin{tabular}{ll}
\hline $\begin{array}{l}\text { Program elements } \\
\text { (cont'd.) }\end{array}$ & Early childhood social and emotional learning programs: Support ways to \\
& $\begin{array}{l}\text { overcome barriers to identifying and serving children and families in need of } \\
\text { services and to identify and consult appropriate community partners in developing } \\
\text { services to address early childhood social and emotional learning programs. }\end{array}$ \\
\hline $\begin{array}{l}\text { Selected grant } \\
\text { requirements }\end{array}$ & - Memorandum of agreement among required partners \\
& - Logic model of the proposed project \\
& - Use of evidence-based programs \\
& - Local evaluations conducted by grantees
\end{tabular}

Source: GAO analysis of documents from SAMHSA and Department of Education. GAO analysis of Department of Education, "Safe Schools/Healthy Students Initiative," 2007, http://www.ed.gov/programs/dvpsafeschools/index.html (accessed August 6, 2007).

aLEAs are public boards of education or other public authorities legally constituted within a state for either administrative control or direction of, or to perform a service function for, public elementary or secondary schools in a city, county, township, school district, or other political subdivision of a state, or for a combination of school districts or counties that are recognized in a state as administrative agencies for their public elementary or secondary schools.

${ }^{\text {b}}$ The Department of Justice contributed funding and administrative support to the SS/HS program from 1999 through 2003. While the Department of Justice signs the collaborative agreement that guides the program, the agency no longer provides funding or administrative support.

${ }^{\circ}$ The SS/HS program also supports efforts focused on early education for children.

${ }^{d}$ According to the SS/HS Fiscal Year 2007 Application Procedures, a logic model is a graphic presentation of the project in chart format that shows, by element: identified needs and gaps, goals, objectives, activities, partners' roles, outcomes, and processes for measuring outcomes. 


\section{Enclosure IV}

Comments from the Department of Health and Human Services

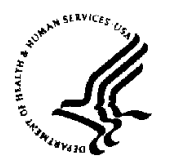

Cynthia A. Bascetta

Director, Health Care

U.S. government Accountability Office

Washington, DC 20548

Dear Ms. Bascetta:

Enclosed are the Department's comments on the U.S. Government Accountability Office's (GAO) draft report entitled, "School Mental Health: Role of the Substance Abuse and Mental Health Services Administration and Factors Affecting Service
Provision" (GAO 08-19R).

Washington, D.C. 20201

The Department found the report to be well written and accurate in its portrayal of the Center's school mental health initiatives and SAMHSA related collaborations with other Federal partners. School-based mental health is an important venue for the delivery of prevention and treatment programs, services and supports for children and families. Your report recognizes and supports this important role.

The Department appreciates the opportunity to comment on this report before its publication.

Sincerely,

$$
\text { Preuntemud }
$$

for Vincent J. Ventimiglia

Assistant Secretary for Legislation 
Enclosure V

\section{GAO Contact and Staff Acknowledgments}

\section{GAO Contact}

Cynthia A. Bascetta, (202) 512-7114 or bascettac@gao.gov

\section{Acknowledgments}

In addition to the person named above, Helene F. Toiv, Assistant Director; Jennie F. Apter; Emily R. Gamble Gardiner; Jeremie C. Greer; Neetha Rao; and Jennifer Whitworth made key contributions to this report. 
This is a work of the U.S. government and is not subject to copyright protection in the United States. The published product may be reproduced and distributed in its entirety without further permission from GAO. However, because this work may contain copyrighted images or other material, permission from the copyright holder may be necessary if you wish to reproduce this material separately. 


\section{GAO's Mission}

The Government Accountability Office, the audit, evaluation, and investigative arm of Congress, exists to support Congress in meeting its constitutional responsibilities and to help improve the performance and accountability of the federal government for the American people. GAO examines the use of public funds; evaluates federal programs and policies; and provides analyses, recommendations, and other assistance to help Congress make informed oversight, policy, and funding decisions. GAO's commitment to good government is reflected in its core values of accountability, integrity, and reliability.

Obtaining Copies of GAO Reports and Testimony
The fastest and easiest way to obtain copies of GAO documents at no cost is through GAO's Web site (www.gao.gov). Each weekday, GAO posts newly released reports, testimony, and correspondence on its Web site. To have GAO e-mail you a list of newly posted products every afternoon, go to www.gao.gov and select "E-mail Updates."

\section{Order by Mail or Phone}

The first copy of each printed report is free. Additional copies are $\$ 2$ each. A check or money order should be made out to the Superintendent of Documents. GAO also accepts VISA and Mastercard. Orders for 100 or more copies mailed to a single address are discounted 25 percent. Orders should be sent to:

U.S. Government Accountability Office

441 G Street NW, Room LM

Washington, DC 20548

To order by Phone: Voice: (202) 512-6000

TDD: (202) 512-2537

Fax: (202) 512-6061

To Report Fraud,

Waste, and Abuse in Federal Programs

Congressional Relations
Contact:

Web site: www.gao.gov/fraudnet/fraudnet.htm

E-mail: fraudnet@gao.gov

Automated answering system: (800) 424-5454 or (202) 512-7470

Gloria Jarmon, Managing Director, JarmonG@gao.gov, (202) 512-4400

U.S. Government Accountability Office, 441 G Street NW, Room 7125

Washington, DC 20548

Susan Becker, Acting Manager, BeckerS@gao.gov, (202) 512-4800

U.S. Government Accountability Office, 441 G Street NW, Room 7149

Washington, DC 20548 